\title{
Urbanization and the advent of regional conservation: Huancayo and the Cordil- lera Huaytapallana, Peru
}

\author{
Andreas Haller \& Hildegardo Córdova-Aguilar
}

Keywords: regional protected area, glacier, mountain city, ecosystem services, Andes, Peru

\section{Abstract}

Since the turn of the millennium, the Peruvian protected-area system has provided regional governments with the possibility of initiating and managing Regional Conservation Areas, a category that complements the system of national protected areas. Regional capitals and other Andean cities welcome this opportunity, and increasingly use this instrument to safeguard important ecosystem services. The city of Huancayo and the Cordillera Huaytapallana are a case in point that underlines the need to integrate cities and protected areas in planning and policy making, and to promote conflict-free development along the urban-rural continuum.
Profile

Protected area

Cordillera

Huaytapallana

Mountain range

\section{Andes, Peru}

\section{Introduction}

In the western world, the rise of modern nature conservation is closely intertwined with the increasing urbanization that marked the $19^{\text {th }}$ century (see Doran \& Richardson 2010), and since the 1980s protected areas (PAs) have expanded globally (Zimmerer et al. 2004). The South American office of the IUCN has stated that increasing urbanization processes have improved the acceptance of PAs, as more and more of the population have become aware of the importance of natural resources and ecosystem services. In the IUCN's words: "In fact, the issue of the relationship between protected areas and urban systems is becoming increasingly important in the region. However, in rural areas there are still conflicts with the inbabitants, due to the imbalance in the distribution of the costs and benefits of conservation, usually manifested in the limited access to the PAs and use of resources". (UICN-Sur 2003, p. 24; translated by the authors)

Payments or compensation for ecosystem services are being trialled in some parts of Latin America, such as Costa Rica, where there are legal structures to benefit smallholders for not felling the forest (Méndez Rodriguez 2011). Other examples are compensation for hydrologic headwater conservation, and carbon capture (Charchalac Santay 2012). Most of these examples refer to the conservation of tropical forest areas; only a few are in the sierra, such as the work of the Fondo Ambiental para la Protección de las Cuencas y Agua (Environmental Fund for the Protection of Basins and Water) in Quito, Ecuador. Using the case of Huancayo and the Cordillera Huaytapallana, this report aims to illustrate that in Peru such developments are likely to increase due to the advent of regional conservation, which can be initiated and managed by regional governments.

\section{Peru: urbanization and conservation}

The geography of Peru, like the Andes in general (Córdova-Aguilar 2009; Borsdorf \& Stadel 2015), is

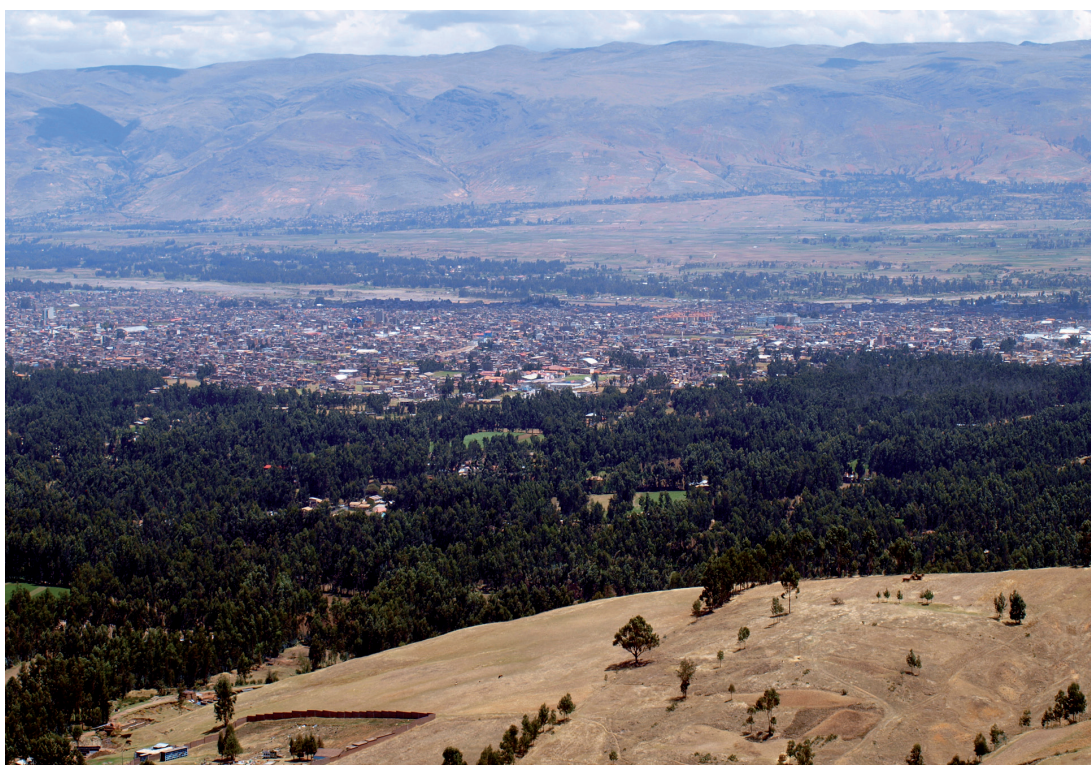

Figure 1 - The metropolitan area of Huancayo is located in the Mantaro Valley of Peru. (C) Andreas Haller.

characterized by verticality. In the 1940 s, this motivated Peruvian geographer Javier Pulgar Vidal to develop his model of eight natural regions (Pulgar Vidal 1996): the Pacific coast or chala (up to $500 \mathrm{~m}$ asl), the yunga maritima (500-2300 m), the quechua $(2300-3500 \mathrm{~m})$, the suni/jalca $(3500-4000 \mathrm{~m})$, the puna (4000-4800 m), and the janca (above $4800 \mathrm{~m}$ ). On the eastern Andean slopes, below the quechua, he distinguishes the yunga fluvial (1000-2300 m), the ruparupa $(400-1000 \mathrm{~m})$, and the omagua $(80-400 \mathrm{~m})$. Despite being a simplification of the geographic reality, the model is heuristically useful (see Zimmerer \& Bell 2013) to illustrate the basic spatial disparities in terms of urbanization and conservation.

In addition to Peru's megacity Lima, today the most important urban settlements are regional capitals and/or economic centres (Córdova-Aguilar 2000). 


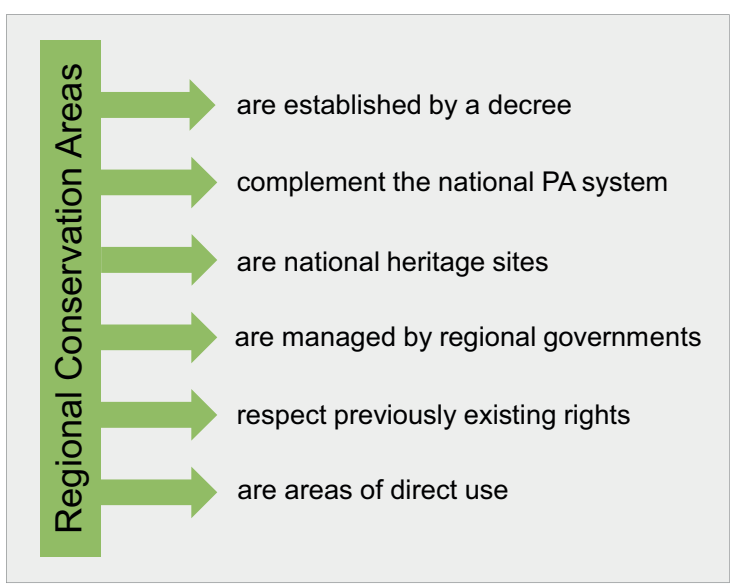

Figure 2 - Characteristics of Regional Conservation Areas. Source: adapted from SERNANP 2013.

The Amazon regions (yunga fluvial, rupa-rupa and omagua), despite accounting for almost $60 \%$ of the national territory, have only seven major intermediate cities (Jaén, Bagua, Moyobamba, Tarapoto, Iquitos, Pucallpa and Madre de Dios). The coast (chala) and the Peruvian sierra represent regions with a significant number of dynamic intermediate cities, especially since the 1960s. According to Young and Rodríguez (2006), the 1960s also marked the start of Peru's conservation period, when a protected-area system was established and the first National Park (Cutervo) was designated. A marked bias towards the conservation of Amazonian forests (probably due to global conservation policies and incentives) could be observed at the beginning of the new millennium, while environments of the coast and sierra, where a significant number of urban centres are located, were under-represented. Even today, 11 out of Peru's 15 National Parks are predominantly Amazonian. In sum, a strong conservation bias towards Amazonia and an urbanization bias toward the coast and the sierra characterized Peru until at least the end of the last century.

In the course of the 1990s, with the economically liberal government of Alberto Fujimori, the protected-area category Área de Conservación Regional (ACR; Regional Conservation Area; see Figure 2) was introduced (Solano \& Monteferri 2009, pp. 13-17), and in 2005 the first PA of this kind was designated (Cordillera Escalera). This category complements the national PA system and enables regional governments, in collaboration with the national PA authority SERNANP, to initiate the process of establishing a protected area on state-owned land that is of local / regional importance. Once established, ACRs can be managed by the regional government or a delegate (SERNANP 2013). Therefore, it comes as no surprise that these PAs are a spatial planning instrument of growing importance to safeguard the provisioning, regulation and cultural ecosystem services demanded by regional urban centres. Contrary to national parks, today's ACRs are not more frequent in Amazonian environments, where only 6 out of 18 PAs are located. An illustrative case is the mountain city of Huancayo and the Cordillera Huaytapallana, which provides urban dwellers and smallholders with vital water resources.

\section{The Cordillera Huaytapallana and Huan- cayo Metropolitano}

The urban agglomeration of Huancayo Metropolitano (Figure 1), located at around $3260 \mathrm{~m}$ in the valleys of the Mantaro River and its tributaries the $\mathrm{Cu}$ nas and Shullcas, is the regional capital of the Junín Region. Over recent decades the city has undergone major growth (Córdova-Aguilar et al. 2005), in terms of both settlement (+44\% during 1988-2008; Haller 2012) and population. The latter doubled between the censuses of 1981 and 2007, and today stands at around 425000 people distributed over seven districts (Haller \& Borsdorf 2013).

A critical issue in this city is the availability of water resources, which are increasingly under pressure due to population and economic growth, poor infrastructure, changing lifestyles, and climatic changes. The area covered by the city's important source of potable water, the Huaytapallana glacier (Figure 3), decreased by 55\% in the period 1984-2011 (López-Moreno et al. 2014). To mitigate the effects of global warming (i.e. drought during the months of May to October), the regional edition of the Peruvian popular newspaper Correo started a campaign on 21 October 2010 calling for the conservation of the Cordillera Huaytapallana:

"Tayta ["father" in Quechua] Huaytapallana, one of the tutelary gods of the Huanca culture, has been mortally wounded and his agony is slow and painful because of the global warming of the Earth, the one that provides all the elements for our subsistence and that we mistakenly mistreat and neglect. That is why the Correo, within the framework of its social responsibility, is today starting a campaign whose main objective is to declare the Huaytapallana mountain range a regional conservation area." (Anonymous 2010, n.p.; translated by the authors)

The campaign was successful and the supreme decree No 018-2011-MINAM that created the ACR Huaytapallana (Figure 4), covering an area of 22406.52 ha in the puna and janca natural regions, was published in the official journal of Peru, El Peruano, on 21 July 2011. The decree underlines the general aim of preserving the region's biodiversity and diversity of habitats, safeguarding the adequate use of water resources for the benefit of the population. Moreover, four specific aims are listed: (1) to conserve and restore high-Andean ecosystems such as grasslands, wetlands, lakes or nival ecosystems; (2) to promote sustainable tourism and other human uses that contribute to maintaining the PA; (3) to improve the capacities of the regional government in protectedarea management; and (4) to develop environmental education for local people, to strengthen research in, and to facilitate access to, information about the 


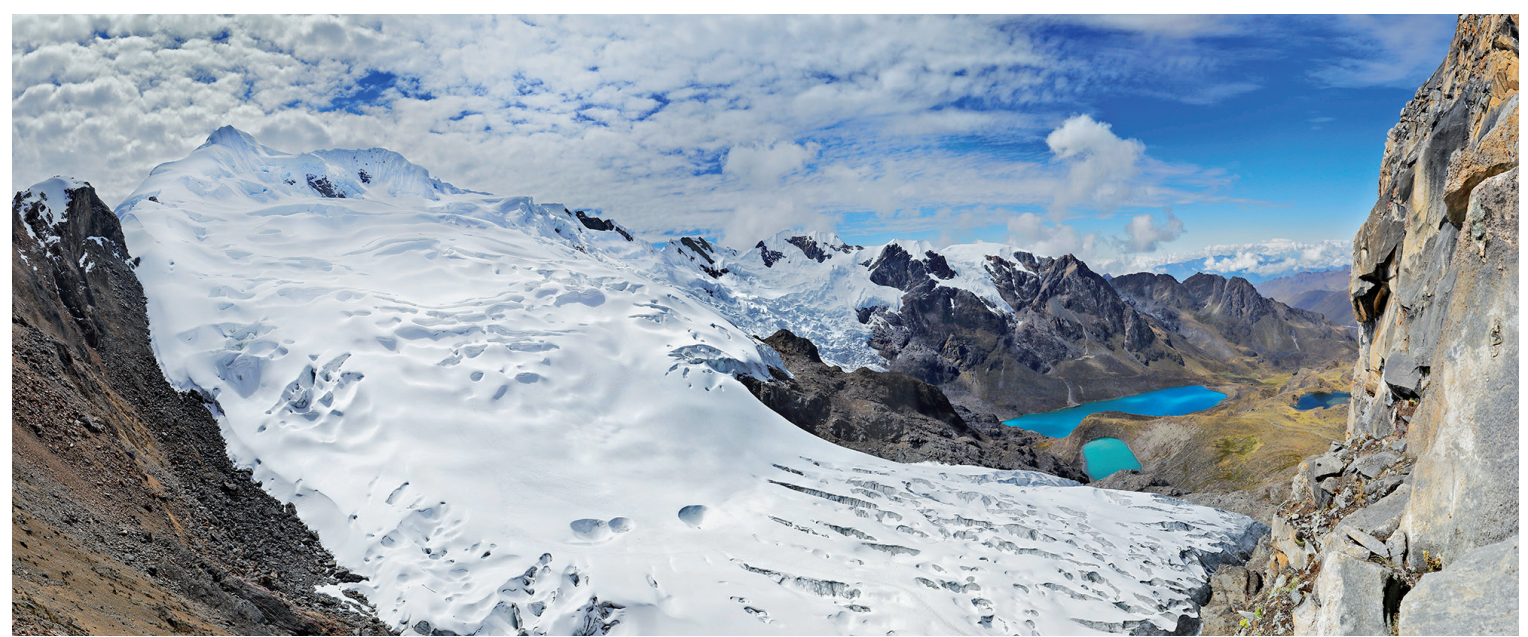

Figure 3 - The Cordillera Huaytapallana is part of Central Peru's eastern cordillera. (C) Jonathan Chancasana

PA. Put simply, the decree explicitly permits the use of renewable resources while restricting the exploitation of nonrenewable resources (Anonymous 2011, p. 446882-446883), a fact which is particularly important for the five agrarian communities adjacent to the PA (GRRNGMA 2014, p. 41-58). The designation, however, also brought potential for conflict in the Shullcas River watershed.

As a result of demographic and physical urbanization in the lower Shullcas Valley, driven in part by the urban populations' search for environmental amenities (Haller 2017), peri-urban smallholders lost large areas of arable and irrigated land on the valley floor, and consequently intensified and / or expanded agricultural land use in the uplands. In the puna, for instance, recent research has indicated the expansion of range burning for livestock grazing (Haller 2012; see also Haller 2014). In the PA, this led to debates on the substitution of cattle and sheep by alpacas, which are better adapted to the fragile high-Andean environment. On 18 June 2013, the Correo stated that: "the camelids will gradually replace cattle and sheep, species that, by their physical characteristics and eating habits, destroy the ecosystem, because when they eat they pull out the grasses with the whole root, unlike the alpacas, which cut the grass. Another advantage of the alpacas is the arrangement of their feet, which have plantar pads that preserve the pastures." (Anonymous 2013a, n.p.; translated by the authors)

This must be seen in the light of the findings of Arroyo Aliaga et al. (2012), who state that grazing in the ablation zone of the Huaytapallana glacier accelerates the loss of glacier mass. Consequently, trade-offs between the provision of grassland for grazing and the provision of water emerge.

A second issue underlining potential for conflict relates to trade-offs between spiritual practices and the provision of clean potable water. The Huaytapallana represents a sacred place for some sections of the local population. Regularly, Andean shamans come up and pay tributes to the $а р u$ or mountain deity. (Interestingly, these rituals have increased since the 1990s; see Matayoshi 2015; Paerregaard 2018.) These practices meet with more and more criticism from the PA authorities, because the waste produced by the so-called pagapus (offerings) contaminates the water resources that subsequently flow down to the peri-urban and urban areas. On 25 July 2013, the following statement could be read in the Correo: "[S]ome Andean priests failed to comply with the previous agreements and contaminated [the Huaytapallana] with bottles, plastics and fruits, which were even thrown into the Lasuntay glacial lake. Some drunken people were also seen bathing in this lake, so they were removed by the park rangers. Therefore, at a future meeting, the Management Committee of this Regional Conservation Area will be asked to probibit the entry of Andean priests and shamans who have failed to comply with the agreements not to contaminate the Huaytapallana." (Anonymous 2013b, n. p.; translated by the authors)

These two examples illustrate potential lines of conflict between different stakeholder groups - between urban/modernist and rural/traditionalist sections of the population - confirming the IUCN's observation cited at the start of this article. Although such a dichotomous understanding can be heuristically useful, rural-urban linkages are strongly marked in Andean cities like Huancayo, and they require a vision beyond binary oppositions. For example, CórdovaAguilar et al. (2005) show that the local identity of the urban population of Huancayo builds strongly on the rural hinterland, which extends up to the snowcovered peaks.

\section{Conclusions and outlook}

The Andes provide indispensable resources for human life, such as water (see also Córdova-Aguilar 2009, p. 18), and Regional Conservation Areas are a promising instrument for regional capitals to safeguard these resources in times of global warming. In Huancayo, Peru, physical, demographic and cultural urbanization is increasing pressure on agrarian land use and driving environmental degradation in higher 

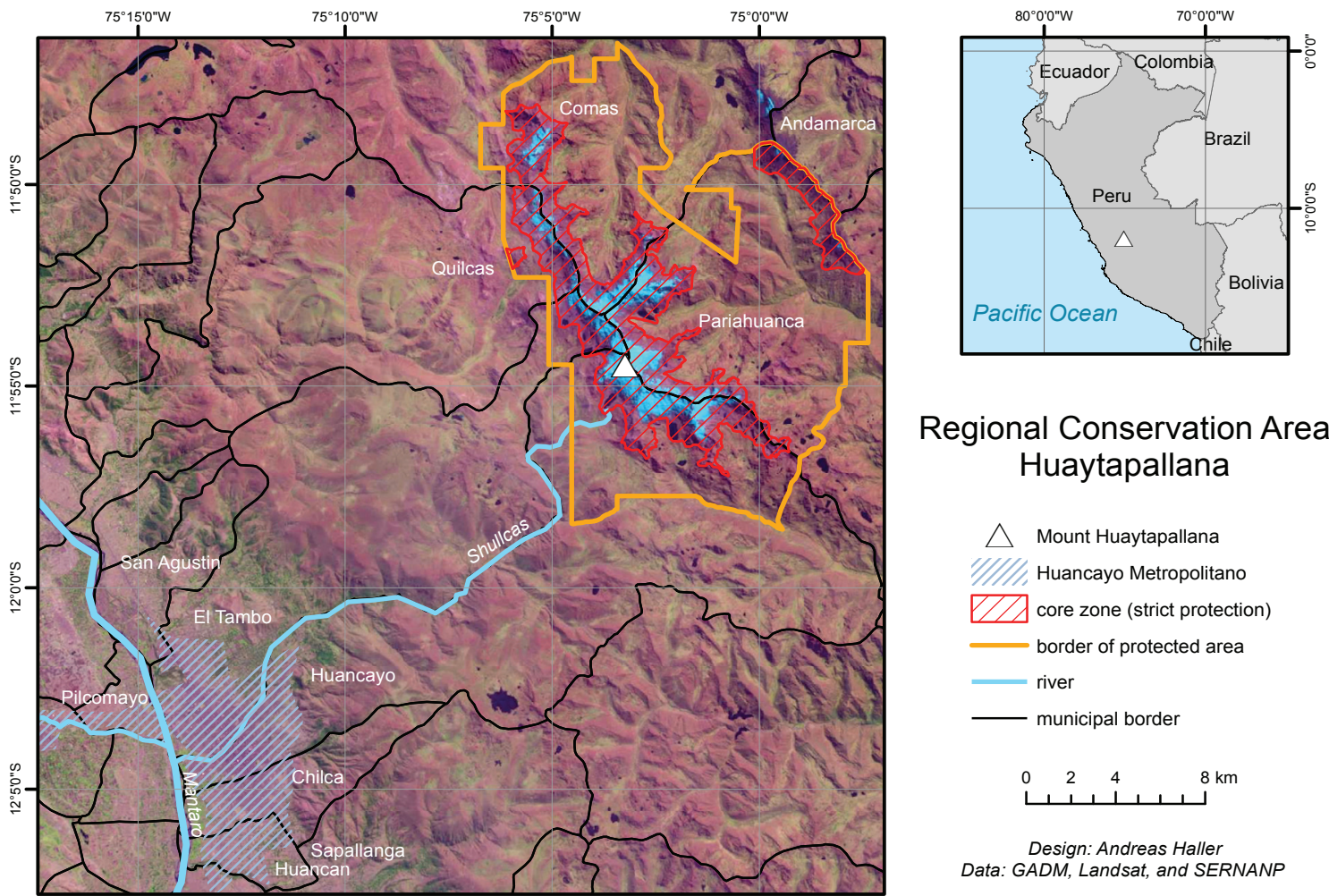

\section{Regional Conservation Area Huaytapallana}

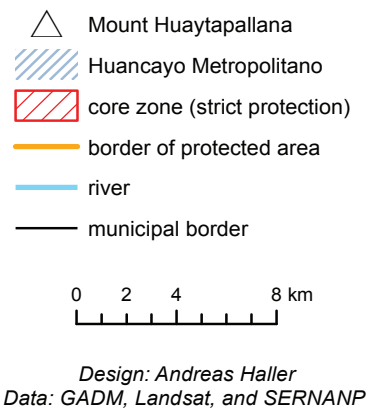

Figure 4 - The Regional Conservation Area Huaytapallana near Huancayo Metropolitano. Source: authors

altitudinal zones of the hinterland, which in turn requires protection policies to safeguard the ecosystem structures and functions that provide services. Yet the benefits of conservation must reach both urban populations and smallholders. If urban dwellers demand ecosystem services such as water regulation, then they should support the smallholders in return for the many restrictions linked with conservation in the puna. From an economically liberal point of view, payment for ecosystem services could be a logical consequence. However, such a system would require a clear legal status, which currently scarcely exists, for smallholders' land tenure (as individuals and / or communities) and land-use rights. Moreover, any formal agreements should also consider traditional regulations of resource use.

Andean regional urban centres are expected to grow steadily in terms of population and settlement, and ACRs initiated and managed by regional governments might be a promising instrument to safeguard ecosystem services. In this context, the inclusion of the local population and the establishment of a scientific council (see Arpin et al. 2016) are necessary endeavours. To make ACRs a success, it is crucial that both urban populations and smallholders develop a high degree of empathy, valorizing each other and becoming aware that they depend on each other, as do both mountain cities and protected areas.

\section{References}

Anonymous 2010. La lenta agonía del Huaytapallana. Correo 21 October: n.p. Huancayo. Available at: https://diariocorreo.pe/ciudad/la-lenta-agonia-delhuaytapallana-435913/ (accessed 31/01/2018) [In Spanish]

Anonymous 2011. Decreto Supremo que establece el Área de Conservación Regional Huaytapallana: Decreto Supremo Nº18-2011-MINAM. El Peruano 21 July: 446882-446883. Lima. [In Spanish]

Anonymous 2013a. Poblarán Nevado del Huaytapallana con alpacas. Correo 18 June: n.p. Huancayo. Available at: https://diariocorreo.pe/ciudad/poblaran-nevado-del-huaytapallana-con-alpaca-93067/ (accessed 31/01/2018) [In Spanish]

Anonymous 2013b. Prohibirán ingreso de chamanes al Huaytapallana. Correo 25 July: n.p. Huancayo. Available at: https://diariocorreo. pe/ciudad/prohibiran-ingreso-de-chamanes-alhuaytapall-87024/ (accessed 31/01/2018) [In Spanish]

Arpin, I., A. Wallner, T. Scheurer \& V. Braun 2016. Recommendations for establishing or renewing scientific councils in protected areas. eco.mont 8(1): 62-65. Vienna. https://doi.org/10.1553/eco.mont-8-1s62

Arroyo Aliaga, J., N. Schulz \& P. Gurmendi Párraga 2012. Impactos de las actividades antrópicas en el nevado Huaytapallana. Apuntes de Ciencia \& Sociedad 2(1): 3-14. Huancayo. https://doi.org/10.18259/ acs.2012002 [In Spanish]

Borsdorf, A. \& C. Stadel 2008. The Andes: a geographical portrait. Cham. 
Charchalac Santay, S. 2012. Experiencias en compensación por servicios ambientales en América Latina (PSA o REDD+). Descripción de casos relevantes. Washington, D.C. Available at: http://www.foresttrends.org/documents/files/doc_3263.pdf (accessed 02/13/18) [In Spanish]

Córdova-Aguilar, H. 2000. El sistema urbano del Perú a partir de 1940. Espacio y Desarrollo 12: 217-239. Lima. [In Spanish]

Córdova-Aguilar, H. 2009. Ventajas y desventajas del desarrollo rural sostenible en ambientes de montaña. Espacio y Desarrollo 21: 7-19. Lima. [In Spanish]

Córdova-Aguilar, H., N. Bernex \& K. Goluchowska 2005. Homogeneidad y diversidad en el patrimonio urbano: casos de El Carmen, San Pedro de Lloc y Huancayo. Espacio y Desarrollo 17: 90-205. Lima. [In Spanish]

Doran, N.E. \& A.M.M. Richardson 2010. History of biodiversity conservation, protected areas and the conservation movement. In: Lorenzano, P., H.J. Rheinberger, E. Ortiz \& C. Delfino Galles (eds.), History and philosophy of science and technology. Volume II: 5588. Oxford.

GRRNGMA [Gerencia Regional de Recursos Naturales y Gestión del Medio Ambiente] (eds.) 2014. Plan Maestro del Área de Conservación Regional Huaytapallana: Plan Maestro 2014-2018. Huancayo. [In Spanish]

Haller, A. 2012. Vivid valleys, pallid peaks? Hypsometric variations and rural-urban land change in the Central Peruvian Andes. Applied Geography 35 (1-2): 439-447. Amsterdam. https://doi.org/10.1016/j.apgeog.2012.09.009

Haller, A. 2014. The "sowing of concrete": periurban smallholder perceptions of rural-urban land change in the Central Peruvian Andes. Land Use Policy 38: 239-247. Amsterdam. https://doi.org/10.1016/j. landusepol.2013.11.010

Haller, A. 2017. Urbanites, smallholders, and the quest for empathy: prospects for collaborative planning in the periurban Shullcas Valley, Peru. Landscape and Urban Planning 165: 220-230. Amsterdam. https:/ / doi.org/10.1016/j.landurbplan.2016.04.015

Haller, A. \& A. Borsdorf 2013. Huancayo Metropolitano. Cities 31: 553-562. Amsterdam. https://doi. org/10.1016/j.cities.2012.04.004

López-Moreno, J.I., S. Fontaneda, J. Bazo, J. Revuelto, C. Azorin-Molina, B. Valero-Garcés, E. MoránTejeda, S.M.Vicente-Serrano, R. Zubieta \& J. AlejoCochachín 2014. Recent glacier retreat and climate trends in Cordillera Huaytapallana, Peru. Global and Planetary Change 112: 1-11. Amsterdam. https://doi. org/10.1016/j.gloplacha.2013.10.010

Matayoshi, N. 2015. Huaytapallana y Pariacaca, los dioses vivientes. Perspectivas Latinoamericanas 12: 1-26. Nagoya. [In Spanish]

Méndez Rodríguez, A. 2011. Experiencia de Costa Rica en el pago de servicios ambientales. San José. Available at: http:/ / forestcarbonpartnership.org/sites/fcp/files/ Documents/tagged/19-Pago $\% 20 \mathrm{de} \% 20$ Servicios $\% 20$ Ambientales $\% 20$ FONAFIFO $\% 20$ Costa $\% 20$ Rica $\% 20$ -\%20A.Mendez.pdf (accessed 02/13/18) [In Spanish]

Paerregaard, K. 2018. Power in/of/as water: revisiting the hydrologic cycle in the Peruvian Andes. Wiley Interdisciplinary Reviews: Water e1270: 2-11. Hoboken. https://doi.org/10.1002/wat2.1270

Pulgar Vidal, J. 1996. Geografía del Perú: las ocho regiones naturales, la regionalización transversal, la sabiduria ecológica tradicional. Lima. [In Spanish]

SERNANP [Servicio Nacional de Áreas Naturales Protegidas por el Estado](eds.) 2013. Áreas de conservación regional. Documento de trabajo 5. Lima. [In Spanish]

Solano, P. \& B. Monteferri 2009. Áreas de conservación regionales y áreas de conservación municipales: propuestas para su consolidación. Lima. [In Spanish]

UICN-Sur (eds.) 2003. Áreas Protegidas en Latinoamérica: de Caracas a Durban. Quito. [In Spanish]

Young, K.R. \& L.O. Rodríguez 2006. Development of Peru's protected-area system: historical continuity of conservation goals. In: Zimmerer, K.S. (eds.), Globalization and New Geographies of Conservation: 229-254. Chicago.

Zimmerer, K.S., R.E. Galt \& M.V. Buck 2004. Globalization and multi-spatial trends in the coverage of protected-area conservation (1980-2000). Ambio 33 (8): 520-529. Stockholm. https://doi. org/10.1579/0044-7447-33.8.520

Zimmerer, K.S. \& M.G. Bell 2013. An early framework of national land use and geovisualization: Policy attributes and application of Pulgar Vidal's state-indigenous vision of Peru (1941-present). Land Use Policy 30(1): 305-316. Amsterdam. https://doi. org/10.1016/j.landusepol.2012.03.023

\section{Authors}

\section{Andreas Haller}

is a postdoctoral researcher at the Institute for Interdisciplinary Mountain Research (IGF) of the Austrian Academy of Sciences (ÖAW). He holds a PhD in Geography from the University of Innsbruck. His research interests include settlement geography and landscape research, with a focus on urbanization and land use change. E-mail: andreas.haller@oeaw.ac.at

\section{Hildegardo Córdova-Aguilar}

is a Professor of Geography and the executive director of the Center for Research in Applied Geography (CIGA) of the Pontifical Catholic University of Peru (PUCP). He holds a PhD in Geography from the University of Wisconsin-Madison. He specializes in cultural ecology, with a focus on rural development, and urban environmental planning. 